\author{
Iryna Shevchenko $\mathbb{D}^{\mathbb{D}}$, Vira Shastalo \\ V. N. Karazin Kharkiv National University, Kharkiv, Ukraine \\ \{iryna.shevchenko, vturchenko\}@karazin.ua
}

\title{
The Conceptual Metaphor of Modesty in English and Ukrainian
}

\begin{abstract}
The article focuses on the cultural regulatory concept of MODESTY in English and Ukrainian linguistic construals of the world. The article examines this concept as it is lexicalized in English and Ukrainian in terms of cross-domain mapping and conceptual integration theory. In the corresponding national corpora of fiction, MODESTY serves both as target and source domains, thus forming the range and scope of conceptual metaphors. The article claims that in genetically unrelated languages, conceptual metaphors of MODESTY demonstrate common mental models and mainly vary in their verbal form and in their frequency in discourse. From a cross-cultural perspective, the variation of conceptual metaphors of modesty is motivated not only linguistically but also culturally. In English conceptual metaphors, the source domains cross-mapped onto the target MODESTY are semantically more varied than in Ukrainian. The target domains onto which MODESTY is mapped form semantically similar conceptual metaphors, which differ in their frequency in English and Ukrainian discourses.
\end{abstract}

Keywords: modesty; English; Ukrainian; conceptual metaphor; linguistic construal of the world

\section{Introduction}

Modesty is considered to be one of the most important elements in the value systems of different linguistic and cultural world communities, along with fidelity, dignity, and honour, which determine a person, their life position, personal qualities, and social behaviour (Bartmin'skiı̌, 2005; Chen et al., 2009; Kiklevich, 2013; Potekhina, 2017). The emphasis here, however, is not on the opposition of individual ethnic value systems, but rather on the dominance of certain values in the cognitive and linguistic construals of the world of different nations (Bartmin'skil, 2005).

Currently, there exists an extensive literature on the concept of MODESTY in different languages and cultures, notably in Chinese, English, Russian, Ukrainian, Kalmyk, etc. (Hu et al., 2019; Mushaeva, 2008; Shevchenko, 2011; Turchenko, 2014). The linguistic properties of MODESTY are mainly described in terms of lexical semantics and from a cognitive perspective. In particular, MODESTY is referred to as 'presentational' regulatory linguo-cultural concept (Mushaeva, 2008, p. 4), which belongs to a class of mental units aimed at keeping ethical norms of presentation of self and saving face, for both the speaker and interlocutor. Being a presentational concept, MODESTY characterizes a person's self-presentation in accordance with the moral requirements of a certain linguistic and cultural community. Its constitutive features depend on ethno-cultural, historical and religious issues (Hoffman et al., 2016; Williams, 2014); yet recent developments in cognitive linguistic and cross-cultural studies (Mizin \& Petrov, 2017; Votyakova \& Quero-Gervilla, 2019) have proved the lack of comprehensive culture specific knowledge of such concepts. Given 
this situation, it is necessary to introduce a comparative vector into their analysis in the English and Ukrainian languages and national cognitive construals of the world.

The article below is part of the authors' research project undertaken in V. N. Karazin Kharkiv National University, Ukraine, to study concepts of ethics and aesthetics from a historical cognitive perspective (Shevchenko, 2011, 2017; Turchenko, 2014). In this paper, the metaphorical conceptualization of MODESTY is the object of research and the aim is to define the common and distinctive properties of conceptual metaphors of MODESTY in Ukrainian and English linguistic construals of the world. Conceptual metaphor theory (Kövecses, 2002; Lakoff \& Johnson, 1980) and Cultural Cognitive Linguistics (Sharifian, 2017) serve as the theoretical underpinnings of this research.

The purpose of this paper is twofold. Firstly, to identify the general conceptual features that form the cross-mapping area for cognitive metaphors of MODESTY in the two languages. Secondly, to define what Kövecses (2002) calls the range and scope of conceptual metaphors of MODESTY in the corresponding linguistic construals of the world. To achieve these goals, this introduction will be followed by a description of the material and the methodology of its analysis (section 2). Later, the concept of MODESTY in English and Ukrainian will be examined (section 3). In the next section, the range and scope of conceptual metaphors of MODESTY in the English construal of the world will be identified (section 4.1) and compared with conceptual metaphors of MODESTY in the Ukrainian construal (section 4.2). Finally, the obtained data will be compared, the results of the analysis will be summarised, and conclusions will be drawn. The prospects of future research will also be discussed (section 5).

\section{Material and Methodology of Analysis}

We have claimed (Shevchenko, 2011; Turchenko, 2014) that MODESTY is an attributive regulatory concept of communicative behaviour, which is profiled within the domain MORALITY, mainly within its subdomain COMmUniCATive Behaviour. Among theories of conceptual metaphor, both standard and computational (Ostanina-Olszewska \& Majdzińska-Koczorowicz, 2019; Pascu et al., 2014), we follow Langacker (1987, p. 488), who understands the domain as a coherent area of conceptualization in relation to which semantic units can be characterized. Domains include units of a lower level of schematicity — concepts or frames (Kövecses, 2017; Sullivan, 2013).

Being an abstraction, MODESTY is comprehended through more concrete concepts in the course of metaphorical nomination. In 'standard' conceptual metaphor theory the cross-mapping of a source domain (correlate) and a target domain (referent) yields a conceptual metaphor. Notably, several correlates can be involved in the metaphorical conceptualization of one referent and vice versa. Accordingly, Kövecses distinguishes the 'range of metaphor', which is a group of several source domains (conceptual correlates) used to comprehend a certain target domain (referent) and the scope of metaphor, or the "target domains, to which a given source concept applies" (Kövecses, 2002, pp. 64, 108).

Kövecses also supplies examples of abstract concepts, such as ARGUMENT, HAPPINESS and others, which are characterized through a set of conceptual metaphors as a result of a target domain being characterized by a number of source domains (Kövecses, 2002, p. 107). In such cases of cross-mapping "a central mapping is one from which other mappings derive and which maps the main meaning focus of the source onto the target" (Kövecses, 2002, p. 118).

In our study, MODESTY is considered to be a socially significant cultural value, a manifestation of morality, which is one of the factors shaping the ethical system of the linguo-cultural community of a certain era in general and an individual ethical system in particular. In English and Ukrainian discourse, the concept of MODESTY is represented both by direct nominations and conceptual metaphors. This emphasizes the importance of modesty for the speech communities. As Kiklevich (2017, p. 12) states, the reconstruction of the linguistic construal of the world, based on lexical material, shows that the word-nominated referents or denotations and concepts exist in reality and are present in the minds of individuals as their mental representations. 
More recent multidiscipline approaches have explored the interface between language, culture, and conceptualization (Sharifian, 2017). Cognitive linguistics focuses on meaning as conceptualization and shares this focus with Cultural Linguistics. As Sharifian (2017, p. 34) argues, "Cultural Linguistics explores, in explicit terms, conceptualizations that have a cultural basis and are encoded in and communicated through features of languages".

In modern cognitive linguistics, metaphorical conceptualization is rooted in the theory of conceptual metaphor (Kövecses, 2002, 2017; Lakoff \& Johnson, 1980; Sullivan, 2013, etc.) and is specified in the theory of cross-mapping (Lakoff, 1993, p. 245), according to which certain characteristics of the source domain are projected onto certain characteristics of the target domain. The common features of the target and source domains revealed in this design form a cross-mapping zone (Lakoff, 1993, pp. 203, 245). From the point of view of Fauconnier (Fauconnier, 1997, p. 1), only a few features of the two compared entities participate in cross-mapping.

The source domains of metaphor are not randomly selected; they are certain conceptual equivalents of target domains 'agreed upon' by the linguistic and cultural community in advance. Thus, MODESTY as a source domain is regularly correlated with certain concepts in the target domain PERSON, yielding numerous conceptual metaphors. Their emergence, known as "expansion" (Lakoff, 1993, p. 60), or the splitting of a conceptual metaphor, is the result of the correlation of one target concept with different concepts of the source domain. In particular, this explicates the appearance of a set of mappings between the elements of the target domain MORALITY and the source domain PERSON, where one referent MODESTY can correlate with ASSISTANT, THINKER, SAVIOUR, etc.

The twofold purpose of this paper is achieved by means of a two-stage analysis. The first stage aims to define conceptual features of MODESTY in English and Ukrainian; and the second addresses their cognitive metaphors in the two linguistic construals of the world. At the first stage, English and Ukrainian dictionaries and thesauri served as the material for a semantic analysis (the method was described in Mykhalchuk \& Bihunova, 2019), while sentence fragments from English and Ukrainian fiction supplied examples of MODESTY for its conceptual modelling. At the second stage, the material for the study of conceptual metaphors was taken from the discourse of English and Ukrainian fiction of the $20^{\text {th }}$ and $21^{\text {st }}$ centuries presented in the British National Corpus (BNC; British National Corpus, n.d.), the sub corpus of fiction, and the Ukrainian Language Corpus (ULC; Korpus ukraïns'koï movy, n.d.). The latter, developed by the staff of the Computer Linguistics Laboratory of the Institute of Philology of the Taras Shevchenko National University of Kyiv, was created in 2003 and is constantly updated with subclasses (Journalism, Folklore texts, Poetic language, Scientific texts, etc.). The developers have also generated frequency dictionaries by several sections and authors. Our examples of cognitive metaphors of MODESTY were obtained from the subclass of fiction, which contains 40 million Ukrainian works by authors from different historical periods.

\section{The Concept of Modesty in English and Ukrainian}

The concept of MODESTY is a linguo-cultural concept, i.e. it "belongs to consciousness, is determined by culture, and is objectified in language" (Karasik et al., 2009, p. 9). In Vorkachev's parlance (Vorkachev, 2004, p. 17), the linguo-cultural concept bears spiritual values, both national and global. It is the product of the system of moral norms and lore of a certain society and belongs to the whole speech community. Cultural concepts, such as GOOD, EVIL, etc., characterize the civilizational legacy of mankind and are defined as "a complex multidimensional collective mental formation in which notional, value, and figurative constituents are distinguished" (Karasik et al., 2009, p. 5). They reveal both similarities and significant differences between the English and Ukrainian notions of MODESTY.

The lexico-semantic analysis of dictionaries and thesauri (Oxford Etymology Dictionary; Oxford Learner's Thesaurus (Hornby, 2008)) shows that the meaning of modesty comprises components 
(semes) describing modest behaviour of a person who: 1) does not want to attract attention; 2) avoids talking about one's abilities, qualities; 3 ) keeps a modest way of life; 4) feels shy, embarrassed about nudity, sex; 5) does not intend to boast (Mushaeva, 2008; Shevchenko, 2011). The lexeme modest ("having moderate self-regard") entered the vocabulary of the English language in 1560 (Oxford etymology dictionary, 2020). In 1590, a new seme - "not improper or lewd" - was registered as a part of its lexical meaning, first in relation to women, and later, since 1600-1610, in relation to clothing, requirements, needs, etc. (Oxford etymology dictionary, 2020).

The concept of MODESTY is referred to by the lexemes of the field 'Modesty', which falls into three microfields and their extensions (Turchenko, 2014):

- microfield "Humble" with extensions 'Sheepish' (bashful, constrained, diffident, meek) and "Unpretentious" (reserved, cautious, demure, detached, humble, etc.);

- microfield "Decent" with extensions 'Unostentatious' (decent, delicate, demure, discreet, etc.), 'Proper' (becoming, chaste, coy, decorous, delicate, quiet, reserved, virtuous, etc.), and "Demure" (chaste, celibate, innocent, prudish, virgin);

- microfield "Moderate" with extensions 'Minor' (insufficient, low, lowly, mild, small, etc.) and 'Low' (social status / professional level: low(er)-class, simple, minor, moderate, etc.).

The elements of the microfields "Humble" and "Decent" nominate the concept directly, whereas the elements of 'Moderate' fall behind the concept MODESTY as a moral feature of a person and form a correlative zone of metaphors for indirect nominations of other concepts.

The concept of MODESTY is structured by two slots corresponding to the meanings of words in the microfields "Humble" and "Decent". They form a frame based on the mental scheme of identification (Zhabotinskaia, 2013), which specifies the concept properties. Elements of the slot HUMBLE are united by the hyper-seme "obedient". HUMBLE falls into two extensions depending upon positive or negative connotations: sheepish and UNPRETENTIOUS. The slot DECENT is united by the hyper-seme "proper" and split into three extensions by the scheme of specification. They are unOSTENTATIOUS, PROPER, and DEMURE; their meanings correspond to psychological, sexual, social, and cultural manifestations of modesty.

Though both English and Ukrainian belong to the Indo-European family, they descend from different ancestors and are not sister languages. Compared to English, the use of words skrom-

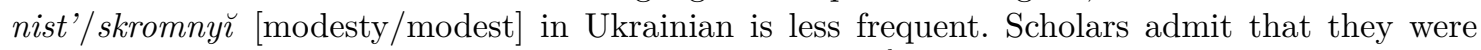
most probably borrowed from Russian language in the $17^{\text {th }}$ century as a result of borrowing from Polish, in which *sromny (from the Czech skrovny) meant 'modest, moderate, insignificant'. In the Old Slavic dialect, *sъkrombnъ is a derivative from the stem *kromı, *kroma (Boryś, 2005), which is an inherited form; it shows the original meaning of the word "one who keeps himself within borders of decency, restrained". These findings suggest that the main version of the origin of the adjective modest is its formation from *kroma ('edge'), adding the prefix * ${ }^{*}$ - with the same motivation (Fasmer, 1986; Rejzek, 2001). In many Slavic languages, the modern meaning of lexemes derived from * sromny is the result of a shift from "the one who limits himself, adheres to certain limits in behaviour" to the current "modest, he who does not expose himself or his merits on display". This semantic shift took place in Polish, from which the lexeme came into Ukrainian through Russian as an intermediary language.

In Ukrainian, the concept is appealed to by the words of the lexico-semantic field SKROMNIST' and its three microfields:

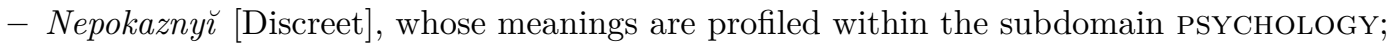

- Tsnotlyvy̆, [Virtuous], with meanings profiled within the subdomain SEX;

- Strymanyı [Restrained], whose meanings are profiled within the subdomain Communicative BEHAVIOUR.

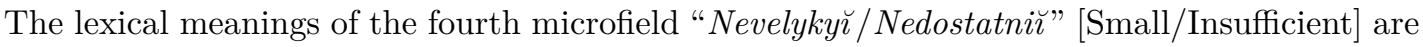
homonymous to modesty and exceed the measures of MORALITY. 
The frame of SKROMNIST ${ }^{\prime}$ is given by the mental scheme of identification. It has three slots, MODESTY IS DISCREET, MODESTY IS VIRTUOUS, and MODESTY IS RESTRAINED, which specify the concept according to the meaning of the thee microfields.

\section{Conceptual Metaphors of Modesty in English and Ukrainian Construals of the World}

As a concept of culture, MODESTY has a distinct sociocultural grounding. In terms of Cultural Linguistic Theory, the 'cultural conceptualization' of modest behaviour occurs in the form of "cultural schemas and cultural metaphors" (Sharifian, 2017, p. 40). The metaphorical actualization of the concept of MODESTY is based on the fact that the metaphor "denies the belonging of an object to the class to which it really belongs, and asserts its relation to a category to which it cannot be rationally attributed" (Arutiunova, 1990, p. 14). In English and Ukrainian fictional discourse, both the range and the scope of conceptual metaphors of MODESTY predictably vary, which is partly explained by the different systems of moral values and norms in the English and Ukrainian construals of the world. The question is to what extent concepts of culture vary and what explains this variation. In other words, it may be asserted that, from a cross-cultural perspective, the metaphoric variation of concepts of culture is not linguistically motivated, but rather culturally motivated.

\subsection{Conceptual Metaphors of Modesty in English}

In our data, the range of metaphors of MODESTY in the English construal of the world is formed by source domains mapped onto the target concept of MODESTY, which is profiled in the domain MORALITY. Among the source domains there are PERSON (which has the highest degree of metaphorization), artifact, container, substance, Cause, and Death. These all belong to the most frequent and common source domains in Kövecses' parlance (Kövecses, 2002, pp. 16-20).

The splitting of the source domain PERSON cross-mapped onto the target concept of MODESTY forms two special cases in English: MODESTY IS A PERSON IN POWER and MODESTY IS AN ACTOR. The first case is illustrated by: Jones's modesty prevented him from speaking in public about the full extent of Crawford's praises $(B N C)$. Here the expression modesty prevented him from speaking indicates modesty as a boss or a leader who has the right to forbid, to allow, to compel, etc.

In the second case, the elements of the source subdomain ACTOR form metaphors:

- MODESTY IS A THINKER: ... its shyness, combined with its great ferocity when cornered, suggests that it would have been troublesome $(B N C)$;

- MODESTY IS AN ASSISTANT: ... shyness that makes you avoid social events may allow you more time and motivation to pursue your solitary goals $(B N C)$;

- MODESTY IS A PERSON who is able to produce emotions, to move or disappear, etc.: You do not lack confidence in your powers. Modesty does not afflict you. (BNC) / Morris' shyness disappeared in a flesh $(B N C)$.

Cross-mappings between the source domain ARTIFACT and the target concept of MODESTY lay out a set of correspondences, such as the ability of an abstraction to be an obstacle, to close or hide something, and so on. This can be illustrated by the following example:

- MODESTY IS AN OBSTACLE: Louise Bowen asked some of the other conference speakers to cast modesty aside and reveal the reasons for their success. (BNC);

- MODESTY IS A COVER: Modesty cloaks many talents (BNC).

The cross-mapping between the target domain MORALITY and the source domain PLANT creates the metaphor MODESTY IS A PLANT, which grows from its roots: This shyness can stem both from personality and lack of confidence $(B N C)$. 
In the $21^{\text {st }}$ century, structural metaphors with a negative rethinking of the traditional value of this virtue appear:

- MODESTY IS DEATH: La! Sir Rowland, your modesty will be the death of you $(B N C)$.

The ontological metaphors include MODESTY IS A CAUSE and MODESTY IS A CONTAINER. The former highlights the correspondence between modesty and the origin of events or states; modesty is understood as causing changes in a person's emotional state or health. The latter illustrates how a moral quality is mentally endowed by physical qualities:

- MODESTY IS A CAUSE: Similarly, shyness is constantly invoked as a legitimate reason for failure to do something $(B N C)$;

- MODESTY IS A CONTAINER: What can have occasioned this sudden lapse into modesty? $(B N C)$.

In the English construal of the world, we have also registered metaphthonymic conceptualizations of modesty. Scholars view metaphthonymy as resulting from the interplay of metonymy and metaphor in discourse (Denroche, 2018). Barnden has proposed alternative views and has argued that the philosophical interpretation of the concepts of similarity and contiguity rather indicates their interpenetration; contiguity is recognized as a generic concept of similarity (Barnden, 2010, p. 172). Such examples as "... modesty not anger causes him to blush frequently" (BNC) confirm the existence of the conceptual metaphtonymy of MODESTY. In this example, modesty is first described as the cause of emotion (metaphor MODESTY IS A CAUSE), then emotion is conceptualized in terms of its manifestation (metonymy COLOUR FOR AN EMOTION).

The scope of metaphors with the correlate MODESTY contains target domains that are adjacent to the domain MORALITY, but do not belong to it and are united by the meaning of quantity or moderation. Kövecses (2002, pp. 62-64) describes MORALITY through the conceptual metaphor MORALITY IS STRENGTH and its antonymous case BEING BAD IS BEING LOW. Our examples have revealed a set of correspondences between elements of the source MODESTY and those of the target domains PERSON (subdomains: APPEARANCE, BEHAVIOUR, SOCIAL STATUS, etc), EMOTION, ARTIFACT, and FOOD/DRINKS, where the first one prevails; it serves as the target for both conceptual metaphors and metonymies.

Being profiled within the domain MODERATION, the concept of MODESTY is nominated by lexemes - members of the microfield "Moderate" and its extensions "Minor", "Low"; MODESTY serves a source for a vast number of target domains, among them PERSON (metaphor SOMETHING IS PROPERTIES OF A MODEST PERSON) with target subdomains:

- subdomain APPEARANCE/CLOTHES: quiet/blushing face, innocent eyes;

- subdomain BEHAVIOUR/MANNERS: a proper manner;

- subdomain MENTAL ABILITIES/WISDOM: low intelligence;

- subdomain SOCIAL STATUS/OCCUPATION: the lowly born; humble career, etc;

- subdomain HOPE/FAITH: simple faith;

- subdomain HEART/SOUL: pure, innocent heart, virtuous soul, etc.

Among other target domains, onto which features of MODESTY are mapped, we have established:

- the target domain Eмотіоn embodied through correlates: delicate feeling, pure and holy love, virtuous indignation, a very delicate feeling;

- the domain FOOD/DRINKS: a modest, simple, and scanty meal;

- the domain ARTEFACT: minor luxuries, a humble bed, a modest home, etc. 


\subsection{Conceptual Metaphors of Modesty in Ukrainian}

In Ukrainian conceptual metaphors of MODESTY (target), the source domains mapped onto the target include PERSON, ARTIFEACT, CONTAINER, WAR, and ANIMAL. The conceptual metaphor MODESTY IS A PERSON can be split into metaphors which present modesty in terms of a certain person or their qualities, e.g.,

- MODESTY IS A FRIEND/MODESTY IS A COMPANION: Tak, velych zavzhdy xodyt' u pari zi skromnistiu, - promovyv Vladyk [Yes, greatness is always paired with modesty, - said Vladyk] $\widetilde{(U L C)}$; skromnist' ne zhyve naodyntsi [modesty doesn't live alone] (ULC);

Other cases of the personification of modesty highlight different human abilities:

- MODESTY IS A PERSON able to calm down/impress/adorn: Taka skromnist'dvoiuridnogo brata zaspokoyïla faraona [Such modesty of the cousin comforted the pharaoh] (ULC); “... skromnist' prykrashaie navit' bez zvan' i nagorod" [modesty adorns even without titles and awards] (ULC).

Mappings of the source "a person endowed with power" form metaphorical expansions:

- MODESTY DOES NOT ALLOW/MODESTY FORCES: skromnist' $i$ suvora chesnist' ne dozvolyly komandyru zaiavyty... [modesty and severe honesty did not allow the commander to declare] $(U L C)$; Pryrodna skromnist' prymushuie avtora vmovknuty [Natural modesty forces the author to remain silent] $(U L C)$.

Denoting human properties instead of a person is a case of a 'stand for' relationship, which is metonymic:

- PROPERTY OF BEING MODEST FOR A PERSON: Treba zh zaйty do Skrromnosti [We must visit Modesty] $(U L C)$.

Structural metaphors of MODESTY highlight elements in the source domain ARTIFACT which denote both a 'positive' stereotypical concept of the cultural norms MODESTY and its negative connotations, which have been registered in the discourse of the previous several decades. In comparison with data from the Victorian era (Turchenko, 2014), modern society values modesty far less than before, e.g.:

- MODESTY IS AN ORNAMENT/MODESTY IS A GUIDE: ... skromnist' prykrashaie navit' bez zvan' $i$ nagorod [modesty adorns even without titles and awards] (ULC); ... same na skromnist' ta lagidnu bezposerednist' protiagom vikiv bulo oriientovane choloviche sertse [that is the male heart on which modesty and gentle spontaneity have been oriented for centuries] $(U L C)$.

- MODESTY IS A PATHOLOGY / MODESTY IS A PRIMITIVE FEELING: Tvoia SKROMNIST ${ }^{\prime}$ - tse vzhe patologiia [Your MODESTY is already a pathology] ( $U L C)$; Tsia chornooka vid narodzhennia ne vidala pro take prymityvne pochuttia, iak skromnist [This black-eyed woman was unaware of such a primitive feeling as modesty] $(U L C)$.

Ontological metaphors of MODESTY are formed by cross-mapping between the target and the source domain CONTAINER, e.g.:

- MODESTY IS A CONTAINER and a person can fall into it: Teper laureats'ke zvannia vsix nas

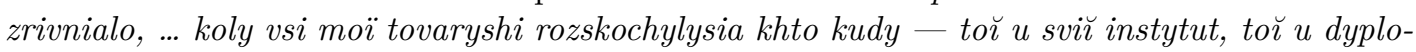
matiiu, a tǒ̆ u skromnist' ia lyshavsia samotoiu... [Now the title of laureate made us all equal,... when all my friends jumped somewhere - one into his institute, another into diplomacy, and the rest into modesty, I was left alone...] $(U L C)$.

Cross-mappings between concepts from the source domain WAR and the target MODESTY form the cognitive metaphor MODESTY IS A WARRIOR: 
- ... Savochka shchosyly pidkresliuvav svoiu voı̆ovnychu skromnist' [Savochka strongly emphasized his militant modesty] $(U L C)$.

In the source domain ANIMAL, the concept of MODESTY is reinterpreted as a beast that 'eats' a person from within, e.g.:

- metaphor MODESTY IS A BEAST: Nashogo molodogo druga zaïdaie skromnist' [Our young friend is seized by modesty] $(U L C)$.

In Ukrainian, the meanings of the source MODESTY profiled within the domain MODERATION can characterize a vast scope of target domains that share the semantics of insufficient quantity or quality, namely, the target domains PERSON (subdomain APPEARANCE, CLOTHES, OCCUPATION, ACHIEVEMENTs, FEeLINGS), ARTIFACT, and FOOD. In the target domain PERSON, the first two subdomains are the most frequent, forming the largest number of metaphoric expansions, e.g.:

- INAPPROPRIATE APPEARANCE IS AN APPEARANCE OF A MODEST PERSON, INAPPROPRIATE CLOTHES ARE CLOTHES OF A MODEST PERSON: skromnyこ vyd [modest appearance]; skromne vbrannia [modest clothing];

- INAPPROPRIATE OCCUPATION IS POVERTY, INSUFFICIENT ACHIEVEMENTS ARE SHYNESS: skromna vdacha [modest luck]; skromni uspikhy [modest achievements]; skromna avtobiografiia [modest autobiography]; skromni mozhlyvosti [modest abilities], etc.

Structural cognitive metaphors describe artifacts, feelings, and food in terms of modesty and reveal a relatively conventional set of correspondences between the source and target domains:

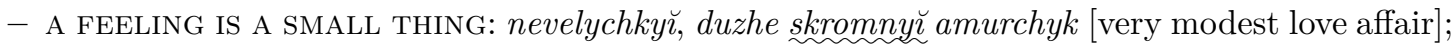

- A MEAL IS A THING OF INSUFFICIENT QUALITY: skromna vecheria [modest supper); duzhe skromni kharchi [very modest meal];

- AN ARTIFACT IS A PROPERTY OF A MODEST PERSON (a car or a house is modest, small, poor,

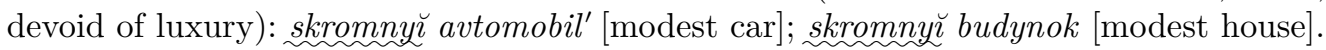

\section{Discussion and Conclusion}

The data obtained in our work show that in the English and Ukrainian construals of the world the metaphorical conceptualization of MODESTY has both common and distinctive features (Table 1). In English and Ukrainian fiction, MODESTY can serve both as the target and source domain of conceptual metaphors. The former include the dominance of metaphors of personification MODESTY IS A PERSON (LEADER, FRIEND, THINKER, etc.) and metaphors MODESTY IS AN ARTIFACT (ORNAMENT/GUIDE/OBSTACLE).

The distinctive features of conceptual metaphors are the comprehension of the target MODESTY through the elements of source domains CONTAINER, CAUSE, SUBSTANCE, and DEATH in the English linguistic construal of the world, and WAR, CONTAINER, and BEAST in the Ukrainian construal.

In the English and Ukrainian construals of the world, MODESTY serves as a source of metaphorical comprehension of other target domains. In both national construals, properties of modesty give way to appeal to a PERSON (APPEARANCE, CLOTHES, BEHAVIOR, MENTAL ABILITIES, SOUL, FEELINGS, SOCIAL STATUS, AND ACHIEVEMENTS), ARTIFACT and FOOD. The main difference between English and Ukrainian cognitive metaphors is mostly manifested in the different frequencies of their use.

Theorists of Cultural Linguistics argue that many features of languages are entrenched in cultural conceptualizations, including cultural models. "Cultural cognition embraces the cultural knowledge that emerges from the interactions between members of a cultural group across time and space" (Sharifian, 2017, p. 38). Mental conceptualization reflects the cultural and socio-historical 
Table 1. The range and scope of cognitive metaphors of MODESTY in English and Ukrainian.

\begin{tabular}{|c|r|c|}
\hline Domains of conceptual metaphors & \multicolumn{2}{|l|}{ National construals of the world } \\
\cline { 2 - 3 } & English & Ukrainian \\
\hline Source domains mapped onto the target concept of MODESTY \\
\hline PERSON & 16 & 20.5 \\
\hline ARTIFACT & 10.5 & 18 \\
\hline CONTAINER & 6 & - \\
\hline CAUSE & 7 & - \\
\hline WAR & - & 5.5 \\
\hline DEATH & 4 & - \\
\hline SUBSTANCE & 4 & 4 \\
\hline BEAST & - & 2 \\
\hline OTHER & 2.5 & 38.5 \\
\hline Target domains onto which the source MODESTY is mapped \\
\hline PERSON & 43.5 & 4 \\
\hline ARTIFACT & 2.5 & 7 \\
\hline FOOD/DRINKS & 2 & 0.5 \\
\hline Other & 2 & 100 \\
\hline Total & 100 & - \\
\hline
\end{tabular}

specificity of speech communities, and this is especially prominent in the system of moral norms and traditions of communicative behaviour.

Generally, our data show that in the two national construals of the world, the range and scope of conceptual metaphors of MODESTY differ: while the sets of their source and target domains are relatively comparable, the frequencies of certain metaphors functioning in discourse significantly vary. The former can be tentatively explained by the role of modesty as an ethical value for English and Ukrainian speech communities, the cultural and religious proximity of national cultures, as well as general principles of metaphorical conceptualization of abstract concepts in more specific terms; while the latter can be ascribed to the linguistic differences between Germanic and Slavic languages.

To conclude, this paper reveals that the concept of MODESTY in English and Ukrainian has common semantic properties, though its frame structure varies from a three-slot identification frame in English to a two-slot frame in Ukrainian. We claim that in genetically unrelated languages the conceptual metaphors of MODESTY demonstrate common mental models and mainly vary in their verbal form and in their frequency in discourse.

In English conceptual metaphors, the source domains cross-mapped onto the target MODESTY mainly comprise PERSON, ARTIFACT, CONTAINER, CAUSE, DEATH, and SUBSTANCE, while in Ukrainian they are PERSON, ARTIFACT, WAR, and BEAST. The target domains, onto which the source MODESTY is mapped, in both national discourses include PERSON, ARTIFACT, and FOOD/DRINKS, but their frequency is different.

The prospect of further research into concepts of culture is foreseen in the study of linguistic and cultural properties of conceptual metaphors in English, Ukrainian, Polish, Russian and other construals of the world from cross-cultural and historical perspectives. 


\section{References}

Arutiunova, N. (1990). Metafora i diskurs. In N. Arutiunova (Ed.), Teoriia metafory (pp. 5-33). Progress.

Barnden, J. (2010). Metaphor and metonymy: Making their connections more slippery. Cognitive Linguistics, 21(1), 1-34. https://doi.org/10.1515/cogl.2010.001

Bartmin'skiŭ, E. (2005). Iazykovoŭ obraz mira: Ocherki po ètnolingvistike. Indrik.

Boryś, W. (2005). Stownik etymologiczny języka polskiego. Wydawnictwo Literackie.

British National Corpus [BNC]. (n.d.). Retrieved February 12, 2020, from http://corpus.byu.edu/bnc

Chen, S., Bond, M., Chan, B., Tang, D., \& Buchtel, E. (2009). Behavioral manifestation of modesty. Journal of Cross-Cultural Psychology, 40(4), 603-626. https://doi.org/10.1177/0022022108330992

Denroche, C. (2018). Text metaphtonymy: The interplay of metonymy and metaphor in discourse. Metaphor and the Social World, 8(1), 1-24. https://doi.org/10.1075/msw.16011.den

Fasmer, M. (1986). Etimologicheskǐ slovar' russkogo iazyka. Progress.

Fauconnier, G. (1997). Mappings in thought and language. Cambridge University Press.

Hoffman, M., Yoeli, E., \& Navarrete, C. (2016). Game theory and morality. In T. Shackelford \& R. Hansen (Eds.), The evolution of morality: Evolutionary psychology (pp. 289-316). Springer. https: //doi .org/10.1007/978-3-319-19671-8_14

Hornby, A. (2008). Oxford learner's thesaurus. Oxford University Press.

Hu, X., Zhu, Y., Yu, F., Wilder, D., Zhang, L., Chen, S., \& Peng, K. (2019). A cross-cultural examination on global orientations and moral foundations. PsyCh Journal, 9(1), 108-117. https://doi.org/10. 1002/pchj. 315

Karasik, V., Krasavskiŭ, N., \& Slyshkin, G. (2009). Lingvokul'turnaia kontseptologiia. Paradigma.

Kiklevich, A. (2013). Sotsial'nye tsennosti v sisteme sovremennoŭ kul'tury. Przeglad Wschodnioeuropejski, 4, 273-294.

Kiklevich, A. (2017). IAzykovaia kartina mira kak problema antropologicheskoŭ lingvistiki. Filologicheskie nauki, 2017(1), 9-16. https://doi.org/10.20339/PhS.1-17.009

Korpus ukrä̈ns'koï movy [ULC]. (n.d.). MOVA.info: Linhvistychnyŭ portal. Retrieved June 10, 2020, from http: //www . mova.info/corpus2.aspx?tid=11996

Kövecses, Z. (2002). Metaphor: A practical introduction. Oxford University Press.

Kövecses, Z. (2017). Levels of metaphor. Cognitive Linguistics, 28(2), 321-347. https://doi.org/10. $1515 / \operatorname{cog}-2016-0052$

Lakoff, G. (1993). The contemporary theory of metaphor. In A. Ortony (Ed.), Metaphor and thought (2 $2^{\text {nd }}$ ed., pp. 202-252). Cambridge University Press.

Lakoff, G., \& Johnson, M. (1980). Metaphors we live by. Chicago University Press.

Langacker, R. (1987). Foundations of cognitive grammar. Stanford University Press.

Mizin, K., \& Petrov, O. (2017). Metaphorical modelling of cognitive structure of concept stinginess in British, German, Ukrainian, Russsian linguocultures. Przeglad Wschodnioeuropejski, 8(1), 219-226. https://doi.org/10.31648/pw.3614

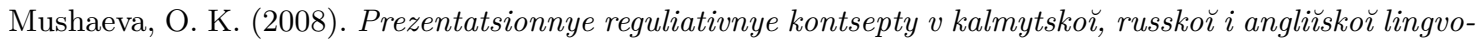
kul'turakh [Unpublished summary of doctoral dissertation]. Volgogradskiŭ gosudarstvennyı̆ pedagogicheskiŭ universitet.

Mykhalchuk, N., \& Bihunova, S. (2019). The verbalization of the concept of "fear" in English and Ukrainian phraseological units. Cognitive Studies / Études cognitives, 2019(19), Article 2043. https://doi.org/ $10.11649 /$ cs. 2043

Online etymology dictionary. (n.d.). Retrieved June 20, 2020, from http://www.etymonline.com

Ostanina-Olszewska, J., \& Majdzińska-Koczorowicz, A. (2019). A Cognitive Linguistics approach to internet memes on selected Polish internet sites. Cognitive Studies / Études cognitives, 2019(19), Article 1939. https://doi.org/10.11649/cs.1939

Pascu, A. C., Fu, T.-K., \& Desclés, J.-P. (2014). Toward a computational theory of conceptual metaphor. In Proceedings of the $2^{\text {th }}$ International Florida Artificial Intelligence Research Society Conference, FLAIRS 2014. https://www.researchgate.net/publication/278763552_Toward_ a_Computational_Theory_of_Conceptual_Metaphor

Potekhina, E. (2017). Sistema tsennoster̆ staroobriadtsev-bespopovtsev v istoricheskoŭ retrospektive. Przeglad Wschodnioeuropejski, 8(2), 417-427. https://doi.org/10.31648/pw.3599

Rejzek, J. (2001). Český etymologický slovník. Leda. 
Sharifian, F. (2017). Cultural linguistics. Ethnolinguistic, 28, 34-61. https://doi.org/10.17951/et. 2016.28 .31

Shevchenko, I. (2011). Diskursoobrazuiushchie kontsepty viktorianstva: SKROMNOST' vs KHANZHESTvo. Cognition, Communication, Discourse, 2011(2), 73-84. https://periodicals.karazin.ua/ cognitiondiscourse/article/view/11360

Shevchenko, I. (2017). The evolution of English expressions of modest behavior: Pragmatic-cognitive analysis. In International Cognitive Linguistic Conference (10-14 July 2017, Tartu, Estonia): Book of abstracts (p. 576). http://iclc14.ut.ee/sites/default/files/proovin/files/iclc14_book_of_ abstracts_03.07.2017.pdf

Sullivan, K. (2013). Frames and constructions in metaphoric language. John Benjamins. https://doi. org $/ 10.1075 / \mathrm{cal} .14$

Turchenko, V. (2014). Kohnityvno-komunikatyvni kharakterystyky kontseptu SKROMNIST'/MODESTY $v$ anhlomovnomu dyskursi XIV-XXI stolit' [Unpublished doctoral dissertation]. Kharkivs'kyı̆ natsional'nyı̆ universytet imeni V. N. Karazina.

Vorkachev, S. G. (2004). Schast'e kak lingvokul'turnyı̆ kontsept. Gnozis.

Votyakova, I., \& Quero-Gervilla, E. (2019). Analysis of the concept of strakh/fear and associated actions in Russian and their translation into Spanish. Kalbu studijos / Studies about Languages, 2019(34), 74-90. https://doi.org/10.5755/j01.sal.0.34.21104

Williams, A. (2014). A brief history of modesty. XVII-XVIII, 71, 135-156. https://doi.org/10.4000/ 1718.399

Zhabotinskaia, S. A. (2013). Imia kak tekst: Kontseptual'naia set' leksicheskogo znacheniia (analiz imeni èmotsii). Cognition, Communication, Discourse, 2013(6), 47-76.

The publication was financed at the authors' expense.

The authors declare that they have no competing interests.

Both the authors participated equally in preparing conception and academic editing of this article.

6) This is an Open Access article distributed under the terms of the Creative Commons Attribution 3.0 PL License (http: //creativecommons.org/licenses/by/3.0/pl/), which permits redistribution, commercial and non-commercial, provided that the article is properly cited.

() The Authors 2021

Publisher: Institute of Slavic Studies, Polish Academy of Sciences

Publishing history: Received 2020-11-19; Accepted 2021-02-23; Published 2021-10-11. 